\title{
Tourism and the intangible heritage of the horse
}

Introduction

Sylvine Pickel-Chevalier

\section{(2) OpenEdition}

\section{Journals}

Electronic version

URL: http://journals.openedition.org/tourisme/3016

DOI: 10.4000/tourisme.3016

ISSN: 2492-7503

\section{Publisher}

Éditions touristiques européennes

\section{Electronic reference}

Sylvine Pickel-Chevalier, "Tourism and the intangible heritage of the horse", Mondes du Tourisme [Online], 18 | 2020, Online since 01 March 2021, connection on 15 March 2021. URL: http:// journals.openedition.org/tourisme/3016 ; DOI: https://doi.org/10.4000/tourisme.3016

This text was automatically generated on 15 March 2021.

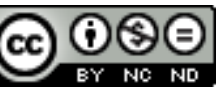

Mondes du tourisme est mis à disposition selon les termes de la licence Creative Commons Attribution - Pas d'Utilisation Commerciale - Pas de Modification 4.0 International. 


\title{
Tourism and the intangible heritage of the horse
}

\author{
Introduction
}

Sylvine Pickel-Chevalier

\section{The horse as a cultural object}

1 Horses have been an integral part of the evolution of human societies throughout history: since antiquity, in Europe, Africa and Asia, and since the modern period, in North and South America. This association is illustrated by practices that vary according to periods and populations. Yet shared across all these periods, is the twofold character of what horses have meant to humans - on the one hand, defined as tools of labour, hunting, transportation and war (Roche, 2008; Lizet, 2020), and on the other, serving as vehicles for the creation of social distinction (Digard, 2007; Roche, 2011). This is due to the fact that the horse has been a unique vector for the improvement of human performance - allowing us to travel more swiftly, with greater power and endurance -, but also to the sheer reality of physical elevation - a person on horseback is spatially situated above those who are on foot. Furthermore, the horse has captured the human imagination since prehistoric times: some 37,000 years ago, the equine acquired the status of the most frequently depicted animal in cave painting (Dubois, 2011)!

2 Because of the complexity of the uses and representations given to the horse, yet also due to the complex character of human-horse relations, in which the animal takes on roles of both object and subject (as seen in $18^{\text {th }}$ century portrayals of the horse within English aristocratic families, which elevated this animal to the ranks of 'individual' (Pickel-Chevalier and Grefe, 2015), the equine has been a key element in the development of societies and worldviews. Horses, ever since their domestication some 5,000 years ago, have contributed to processes of socio-cultural transformation (Digard, 2007). Stimulating the invention of the very materials and tools that in turn made it possible to perfect the means used to exploit them; horses favoured the intensification 
of agriculture, human mobility and the development of cultural and commercial exchange. They also facilitated activities of conquest and produced veritable metamorphoses of modes of existence, as in the case of the nomadisation of the Indians of the North American plains in the $18^{\text {th }}$ century (Roe, 1955).

Taking part in the evolution of social relations of time and space, yet also genetically transformed by societies in order to better respond to their needs (hefty animals for work and cavalry uses, more refined animals for light cavalry or the stylised equitation of the Renaissance court, slender horses for $18^{\text {th }}$ and $19^{\text {th }}$ century sport, etc.), horses are a cultural object. By 'object', we refer to 'a tangible or intangible reality that is constructed, stable and singular, entering into systems of action but not endowed with intentionality' (Ruby and Lévy, 2013, p.731) and by culture, to 'the set of symbolic productions that are available within a given social reality' and 'a way of relating to the world that is common to members of a community' (definitions 2 and 5, Lévy, 2013, p. 238). We define a cultural object as a social construction that is able to function as a producer and vector of meaning, reflecting a way of relating to the world that is common to members of a community. It can be further characterised by its mediating functions within a given socio-historical context (Diet, 2010).

We argue here that the horse, as animal, can also be defined as a cultural object, constructed by societies within their space/time frameworks and in this way, a producer and vector of meanings that are proper to a community. As the horse can be identified as a cultural object, we can also speak of the existence of 'equine cultures', which in turn can be defined as a system of practices and representations related to equines, shared by a community that unites around it. Equine cultures go beyond but also include the notion of equestrian culture, centred more specifically around equitation. In other words, the concept of equine culture is a broad one which covers the whole range of relations constructed around horses and equids, in their diverse functions (ridden, driven, under rein and saddle, at liberty, etc.) and representations.

Equine cultures are numerous, plural, and spread throughout all continents (Adelman and Thompson, 2017), echoing the diverse modes of existence they are a part of. They share, however, the common characteristic of having lost strength to the advance of science and technologies which have - since the $19^{\text {th }}$ century, in the Western European case and following their own specific pace in other parts of the world - put their centuries-old roles in check. Yet rather than having wrought 'the end of the horse' (Raulff, 2018), the $20^{\text {th }}$ century has been testimony of its social recoding, through the prism of affective relationships - the myth of the horse as an alter ego - associated with an "imaginary" that has been shaped, above all, by and within the expanding sphere of popular arts for the young (Pickel-Chevalier, 2017). An imaginary fostered by, and in turn encouraging the development of equestrianism as a leisure practice (PickelChevalier and Grefe, 2015), within new communities of riders that tend to be younger and predominantly female, a worldwide tendency (Adelman and Knijnik, 2013).

\section{The invention of intangible heritage and its relationship to the construction of tourism}

6 This particular evolution has allowed the horse, as with many other cultural objects that have lost all or part of their meaning over time, to become part of the process of heritagisation, yet without undergoing any symbolic rupture (Pomian, 1990). Thus, 
although traditional equine cultures have been called into question by the modern world, they have also led to a new awareness of identities, as well as to concerns regarding their disappearance, most often intertwined, and embedded within a particular relationship to time and history (Hartog, 2012). In fact, it is the process in which the meanings of cultural objects shift within collective consciousness - moving from utility to memory - that allows their redefinition as heritage (Babelon and Chastel, 1994). The cultural heritage is identified by the Council of Europe as:

a group of resources inherited from the past which people identify, independently of ownership, as a reflection and expression of their constantly evolving values, beliefs, knowledge and traditions. It includes all aspects of the environment resulting from the interaction between people and places through time. (European Council, 2005, article 2)

7 However, this concept of heritage has been extended, in particular through the recommendations of French ethnologists, by reference to intangible heritage, identified in 2003 by UNESCO as

practices, representations, expressions, knowledge, skills - as well as the instruments, objects, artefacts and cultural spaces associated therewith - that communities, groups and, in some cases, individuals recognize as part of their cultural heritage. This intangible cultural heritage, transmitted from generation to generation, is constantly recreated by communities and groups in response to their environment, their interaction with nature and their history, and provides them with a sense of identity and continuity, thus promoting respect for cultural diversity and human creativity.' (Convention for the safeguarding of immaterial cultural heritage, 2003, article 2) ${ }^{2}$

8 Intangible heritage is distinguishable from ethnological heritage insofar as it demands 'a notion of effective transmission of practices, along a course that involves sustainable development' (Bortolotto, 2011, p.37). According to the anthropologist Jean-Louis Tornatore, it is an innovative concept which demands that we consider the social actors who take part in the heritagisation processes, and thus implies the notion of 'community', defined by the Council of Europe as: 'people who value specific aspects of cultural heritage which they wish, within the framework of public action, to sustain and transmit to future generations' (European Council, 2005, article 2) ${ }^{3}$. Chiara Bortolotto aligns her work to this approach, reminding us that

the definition insists on the role of social actors ('communities, groups and even individuals, where appropriate') in heritage recognition, considering not only historical dimensions ('transmission from one generation to the next') but also its aspects of process and evolution ('its constant re-creation'), as well as its identity functions for those social actors who through this heritage seek 'a sense of identity' - while remaining within the bounds of non-discriminatory practices and consistent with an emerging global ethics. (2011, p.26)

9 This intangible heritage thus places the community at the centre of its concerns, as a fundamental agent of the transmission, but also signifies the constant regeneration of a living culture in which communities find meaning. Culture can thus be seen as dynamic, as a part of processes of perpetual reconstruction of traditions, whether this happens spontaneously or institutionally (Hobsbawm \& Ranger, 2012).

Tourism plays an essential role in this process. As geographer Olivier Lazzarotti puts it, 'Heritage and tourism are two phenomena that pertain to the same process of production of memory; they are co-constitutive' (2011, p.72). Tourism allows us to promote, as well as reinvent, a part of our heritage (Picard, 1992), recoded, like so many 
other markers of cultural identity, through interactions between endogenous (community) and exogenous actors. The latter include not only public authorities and private companies, but also tourists - since local populations may partially reappropriate the images and projections that tourists make of them (Staszak, 2008). Individual and collective identities emanate from a social construction that involves a relationship to otherness, through a double process of assimilation/distancing (Stascak, Debardieux and Pieroni, 2017), and sometimes of interculturation (Pickel, Violier and Parantika, 2018). Tourism, culture and heritage, more particularly intangible ones, thus feed into each other (Richards 2000; Lazzarotti and Violier, 2007; Hitchcock, King and Parnwell, 2010). This co-construction is notably highlighted, as Frédéric Maguet outlines, by the fact that $85 \%$ of untangible heritage registered on the UNESCO list concerns activity that imply the existence of a public: musical artistic practices, puppet shows, theaters, festivals, etc. (Maguet, 2011, p.34).

\section{Tourism and intangible equine heritage: a new scientific object}

11 We argue here that the horse, as a cultural object, has emerged from its weakening within the contemporary world to become a part of current processes of heritagisation.

Horses, fundamentally associated with systems of practice, knowledge and representation, can thus be understood as a heritage that is both tangible (a socially constructed animal and the equipment associated with it) and intangible (modes of existence) around which group identities emerge. In this light, the horse as a cultural object becomes a stimulating theme of study, inscribed within analyses of the mutual constitution of tourism and heritage. Among the issues that this raises, we highlight the following:

- The characteristics of the communities that recognise themselves in this heritage, through a logic that is inclusive/exclusive, and inquiring into processes of identity construction;

- Relations that are intrinsic to tangible and intangible heritage, and their mutual construction;

- Intergenerational cultural transmission, as it is complexified by the shifting profile of practitioners (from rural/masculine to urban/feminine);

- The fundamental role that tourism plays in these processes, contributing to the conservation of tangible and intangible heritage through dynamics of preservation, adaptation and reinvention.

13 The horse as a cultural object, and thereby as heritage of humanity, is also innovative, insofar as it interpellates a highly complex set of human-animal relations. Today, this specifically invokes the field of interspecies ethnology, and its queries regarding researchers' ability to speak 'of' and 'for', yet from the prism of their own cognition. This latter issue has come to the forefront as part of a movement of new 'animalist' sensibilities, which oppose - and sometimes very vehemently - the attitudes of traditional cultures that entertain more utilitarian relations with horses.

We respond to these questions here by studying equine cultures as intangible heritage that emerges from, and with, the material heritage of the horse, in all its geographic and socio-cultural diversity. Indeed, we may follow ethnologist Jean-Pierre Digard's lead in understanding that the human relationship with equines has given rise to two 
different types of society, elite equestrian societies - in which horses and riding are reserved for a social elite that must master sophisticated equestrian techniques, which in turn testifies to their membership within the privileged classes - and horse peoples in which horses and horsemanship are diffused throughout all social strata of the population, without fundamental distinctions of class, gender or age, and based on simplified, equestrian practices that essentially serve the purposes of transportation, hunting and work (Digard, 2007).

This thematic dossier, which is meant to be both international - covering case studies from seven different countries - and interdisciplinary - integrating perspectives from geography, sociology, anthropology, ethnology and management - in approach, addresses the above-mentioned dichotomy. In the first article, geographer Sylvine Pickel-Chevalier discusses the persistence and continuity of high equestrian arts in France, Spain and Portugal, by analysing modes of operation of the Cadre Noir de Saumur/IFCE, the Real Escuela Andaluza del Arte Ecuestre (Jerez) and Escola Portuguesa de Arte Equestre (Lisbon), which today stand largely reinvented through their affiliation with tourism, a shift that has demanded deep socio-cultural and economic mutations.

In the next article, anthropologist Thomas Apchain examines appropriations of a specific form of intangible equestrian heritage that was added to the UNESCO list in 2011, namely horse riding in the French tradition. He provides a comparative analysis of the French towns of Saumur, Deauville and Chantilly and how they have capitalised on the horse as an identity marker. This raises the issue of territorialisation, largely orchestred through the local logics of tourism development, yet claiming to be a universally-relevant national heritage.

We then move away from the issues of the perpetuation and dissemination of equestrian art within elite equestrian societies, to focus on changes in the practices of horse peoples, which still exist in Europe and around the world. While the horse is no longer necessarily a part of the daily life of the entire population of such societies, it remains a popular cultural object, essential to the identity of rural, semi-rural and even urban communities. In this context, we inquire into tourism's ability to promote the renewal of communities that have been weakened or even challenged by contemporary society.

18 In this vein, anthropologist Letizia Bindi analyses the complexity of ritual equestrian competitions that are a part of popular Italian festivities, such as the Palio de Siena. Condemned by animal rights movements, these events, which re-inscribe traditional utilitarian and rough-style relations to the animal, turn horses into cultural objects at the heart of a controversy. The very notion of culture is called into question, as the cultural significance of the event is defended by the local community but disavowed at the national level. While the tourism that these equestrian competitions generate may give host cities an international visibility and influence that assure them a future, the continuity of such practices also requires socio-cultural changes that are difficult for communities to assimilate.

19 This ambiguous relationship between tourism and the intangible heritages of the horse, favouring their perpetuation at the cost of profound transformations, also characterises certain Brazilian communities. Sociologist Miriam Adelman analyses the particular case of São Luiz do Purunã, example of the emergence of new ruralities resulting from the flow of city dwellers to places they then inhabit and reshape, 
through their own projections and imaginings. In this case, the popular notion of the Gaúcho - South American horseman - still reigns supreme. Yet the local population is obliged to adapt to a new hybrid culture that destabilises traditional rural ways of life and is accentuated by the growth of a service sector based on tourism. Furthermore, tourism activities are based on complex interactions between the native community and exogenous agents in which social reorganisation often reinforces social inequality or intensifies forms of marginalisation.

Another contribution to this dossier examines the heritage of equestrian tourism in Iceland, where horses are, in some regions, more numerous than people. Guðrún Helgadóttir and Ingibjörg Sigurðardóttir, researchers in management sciences, examine the experience of horse-riding tourism in their country as a means of perpetuating an intangible heritage. Indeed, this form of tourism is posed by its practitioners as a way of reconnecting to the partly-reinvented traditional culture of long distance crossings, on old transhumance paths, in the heart of arctic natural environments and on Icelandic horses. They attempt to connect these tourism activities to the conservation of an equine culture, combining tangible heritage - the horse - and intangible heritage - vehicle of mobility and mode of existence - which nevertheless requires adaptations, particularly in terms of logistics, and the hosting of a population that has become overwhelmingly urban.

21 Finally, we look at the limits of how the intangible heritage of the horse can be mobilised through tourism, examining relationships of alterity, through the study of buzkashi (literally, goat-pulling) which is very popular in Central Asia. In her analysis of the Afghan buzkashi played in Kyrgyzstan and Kazakhstan, ethnologist Carole Ferret attempts to decipher the difficulties involved in the 'touristification' of a violent and somewhat anarchic ritual cultural practice. While this ritual is seen as essential for local communities, it also resists adaptation to the new dynamics of tourism - and despite the government's political interest in having this happen. Such adjustment would require a sort of normalisation process that could make the ritual not only accessible and comprehensible, but also acceptable to foreign tourists, especially Westerners, who tend to adhere to a new sensitivity to animals that opposes traditional relations with horses such as those of these Afghan equestrians.

As a set, the articles published here raise pertinent questions regarding the role of tourism in the identification and permanent reinvention of intangible equine heritage. They ask how communities interrogate the construction of their own identities in relation to otherness/alterities, and how processes of dissemination and appropriation of equine cultures unfold within contemporary societies which sometimes oppose their transformation. They point to the conflicts that emerge from conservation policies, requiring logics of adaptation and innovation that induce socio-economic and cultural restructuring, whether or not they are assimilated by the communities concerned.

This dossier, which delves into notions of equine culture, is innovative in terms of its theme, as well as its international and interdisciplinary character, which in turn brings a variety of research methodologies into dialogue. It is emerging from the Horse and Heritage colloquium, co-organised on October 12, 2019 in Saumur, by the ESTHUA Department of Tourism and Culture of the University of Angers and the French Mission for Equestrian Culture. The latter, it is worth adding, is an association whose major goal is to 'act to promote the recognition of all heritages and cultures linked to the horse, as important elements of cultural diversity and creativity, and to encourage and foment 
research in this field of studies'4. Financial support from these two institutions has also been essential to the preparation and publication of this dossier.

\section{BIBLIOGRAPHY}

Miriam ADELMAN and Jorge KNIJNIK, Gender and Equestrian Sport, Springer, 2013.

Miriam ADELMAN and Kirilly THOMPSON, Equestrian Cultures in local and global contexts, Springer, 2017. Jean-Pierre BABELON and André CHASTEL, La notion de patrimoine, Liana-Levi, 1994.

Chiara BORTоцотто (ed.), Le patrimoine culturel immatériel. Enjeux d'une nouvelle catégorie, Éditions de la Maison des sciences de l'homme, 2011.

COUNCIL OF EUROPE, Convention-cadre du Conseil de l'Europe sur la valeur du patrimoine culturel pour la société, 2005 [https://rm.coe.int/1680083748].

Emmanuel DIET, « L'objet culturel et ses fonctions médiatrices », Connexions, vol. 1, no. 93, 2010 [https://www.cairn.info/revue-connexions-2010-1-page-39.htm].

Jean-Pierre DIGARD, Une histoire du cheval, Actes Sud, 2007.

Hélène DUBOIS, Légendaire cheval. Mythes, folklores et traditions, Mens Sana, 2011.

François HARTOG, Régime d'historicité. Présentisme et expériences du temps, Édition du Seuil, 2012.

Eric HOBSBAWM and Terence RANGER, The invention of tradition, Cambridge University Press, 2012.

Michael HITCHCOCK, Victor T. KING and Michael PARNWELL (eds.), Heritage Tourism in Southeast Asia, Nias Press, 2010.

Olivier LAZZAROTTI, Tourisme et patrimoine, Belin, 2011.

Olivier LAZZAROTTI and Philippe VIOLIER, Tourisme et patrimoine : un moment du monde, Presses universitaires d'Angers, 2007.

Jacques LÉVY, « Culture » in Jacques LÉVY and Michel LUSSAULT (eds.), Dictionnaire de la géographie et de l'espace des sociétés, Belin, 2013.

Bernadette LIZET, Le cheval dans la vie quotidienne, CNRS éditions, 2020.

Frédéric MAGUET, « L'image des communautés dans l'espace public » in Chiara BORTOLOTTO (ed.), Le patrimoine culturel immatériel. Enjeux d'une nouvelle catégorie, Éditions de la Maison des sciences de l'homme, 2011.

Michel PICARD, Bali : tourisme culturel et culture touristique, L'Harmattan, 1992.

Sylvine PICKEL-CHEVALIER, « Popular Horse Stories and the Invention of the Contemporary HumanHorse Relationship through an 'Alter Ego' paradigm », Journal of Sports Science, vol. 5, 2017.

Sylvine PICKEL-CHEVALIER, « L'équitation française et sa patrimonialisation dans la société des loisirs », EspacesTemps.net, 2016 [https://www.espacestemps.net/articles/lequitation-francaiseet-sa-patrimonialisation-dans-la-societe-des-loisirs/]. 
Sylvine PICKEL-CHEVALIER and Gwenaëlle GREFE, «Le cheval réinventé par la société des loisirs en Occident : une mythologie révolutionnée ? $\left(\mathrm{XVIII-XXI}{ }^{\mathrm{e}}\right) »$, Cheval, tourisme et sociétés/Horse, Tourism and Societies, Mondes du tourisme, special issue, 2015.

Sylvine PICKEL-CHEVALIER, Philippe VIOLIER and Asep PARANTIKA, « Le tourisme, agent d'interculturation sociospatial? Le cas des pratiques touristiques littorales indonésiennes à Bali et à Java ", L'Espace géographique, vol. 2, t. 47, 2018.

Krzysztof Pomian, « Musée et patrimoine ", in Henri Pierre JEUdy (ed.), Patrimoines en folie, Éditions de la Maison des sciences de l'homme, 1990.

Ulrich RAULFF, Farewell to the Horse, Penguin Book, 2018.

Greg RICHARDS, «Tourism and the World of Culture and Heritage » Tourism Recreation Research, vol. 25 , no. $1,2000$.

Daniel ROCHE, La culture équestre de l'Occident, XVI-XIX' siècle. T1. Le cheval moteur, Fayard, 2008.

Daniel ROCHE, La culture équestre de l'Occident, XVI-XIXe siècle. La puissance et la gloire, Fayard, 2011.

Frank Gilbert ROE, The Indian and the Horse, University of Oklahoma Press, 1955.

Christian RUBY and Jacques LÉVY, « Objet », in Jacques LÉVY and Michel LUSSAULT (eds.), Dictionnaire de la géographie et de l'espace des sociétés, Belin, 2013.

Jean-François STASZAK, «Qu'est-ce que l'exotisme ? », Le Globe, vol. 148, 2008.

Jean-François STASZAK, Bernard DEBARDIEUX and Rafaël PIERONI, « Frontières, altérité, identité », in Jean-François STASZAK (ed.), Frontières en tous genres, cloisonnement spatial et constructions identitaires, Presses universitaires de Rennes, 2017.

Jean-Louis TORNATORE, « La difficile politisation du patrimoine ethnologique » Terrain, no. 42, 2004. UNESCO, Convention pour la sauvegarde du patrimoine culturel immatériel, 2003 [https:// ich.unesco.org/fr/convention].

\section{NOTES}

1. https://rm.coe.int/1680083746

2. https://ich.unesco.org/en/convention

3. https://rm.coe.int/1680083746

4. https://www.equitation-francaise.fr/ 


\section{AUTHOR}

\section{SYLVINE PICKEL-CHEVALIER}

Associate Professor

Research Director in Geography (HDR)

ESTHUA University of Angers

UMR CNRS 6590 Spaces and Societies

Sylvine.chevalier[at]univ-angers.fr 